\title{
ANALISIS JENIS-JENIS PIGMEN ALGA COKLAT Padina australis Hauck DARI PERAIRAN LAUT SULAWESI
}

\section{(Pigmen analysis of Brown Algae Padina australis Hauck from Sulawesi sea)}

\author{
Julia L. Kalalo ${ }^{{ }^{\star}}$, Desy Mantiri ${ }^{1}$, Joice Rimper ${ }^{1}$ \\ 1. Program Studi IImu Kelautan, Fakultas Perikanan dan IImu Kelautan, Universitas Sam \\ Ratulangi, Manado \\ *e-mail : kalalojulia@gmail.com
}

Padina australis Hauck is one of the brown algae that belongs to a class Phaeophyceae, Dictyotales order. This species is very important because it is useful as animal feed, fertilizer, pharmaceutical ingredients, human food and cosmetics. Sample taken in marine waters Sulawesi, precisely in the waters of cape Kalasey, Tongkaina waters, and the waters Blongko. The purpose of this study is to analyze the type of pigment chlorophyll with qualitatively and quantitatively. Process of extraction is done with organic solvent, and the developer with PE and acetone $(80: 20)$. Extraction results then analyzed with a spectrophotometer at a wavelength of $380-700 \mathrm{~nm}$, for the type of pigment chlorophyll. Type of pigment found in the pigment extraction $P$. australis Hauck of three waters is chlorophyll-a and chlorophyll-b, with an average concentration of chlorophyll-a value that is the highest in the waters Blongko $0.381 \mu \mathrm{g} / \mathrm{ml}$ in PTK3, with a range from 0.293 to $0.381 \mu \mathrm{g} / \mathrm{ml}$, and lowest in the waters Tongkaina is 0.143 $\mu \mathrm{g} / \mathrm{ml}$ PT3, with a range from 0.431 to $0.30 \mu \mathrm{g} / \mathrm{ml}$.

Keywords : Brown algae, Padina australis, chlorophyll, cape Kalasey, Tongkaina waters,
waters Blongko

Padina australis Hauck adalah salah satu alga coklat yang termasuk dalam kelas Phaeophyceae ordo Dictyotales. Spesies ini penting karena berguna sebagai pakan ternak, pupuk, bahan sediaan farmasi, makanan manusia, dan kosmetika. Sampel diambil di Perairan Laut Sulawesi tepatnya di Perairan Tanjung Kalasey, Perairan Tongkaina, Perairan Blongko. Tujuan dari penelitian ini adalah menganalisis jenis pigmen klorofil secara kualitatif dan kuantitatif. Proses ekstraksi dilakukan dengan pelarut organik, sedangkan pengembang dengan PE dan aseton (80:20). Hasil ekstraksinya kemudian dianalisis dengan spektrofotometer pada panjang gelombang 380 - $700 \mathrm{~nm}$ untuk jenis pigmen klorofil. Jenis pigmen yang ditemukan pada ekstraksi pigmen $P$. australis Hauck dari tiga perairan adalah klorofil-a dan klorofil-b dengan konsentrasi rata-rata klorofil-a nilai tertinggi di Perairan Blongko yaitu $0,381 \mu \mathrm{g} / \mathrm{ml} \mathrm{di}$ PTK3 dengan kisaran 0,298 $-0,381 \mu \mathrm{g} / \mathrm{ml}$ dan terendah di Perairan Tongkaina yaitu 0,143 $\mu \mathrm{g} / \mathrm{ml}$ di PT3 dengan kisaran $0,143-0,30 \mu \mathrm{g} / \mathrm{ml}$.

Kata Kunci : Alga coklat, Padina australis, klorofil, perairan Tanjung Kalasey, perairan Tongkaina, perairan Blongko

\section{PENDAHULUAN}

Pada umumnya alga hidup pada daerah intertidal. Alga yang hidup di daerah ini dapat dibagi dalam tiga kelompok yakni alga hijau (Chlorophyta), alga merah (Rhodophyta), dan alga coklat (Phaeophyta) (Van den Hoek et al, 1995). Ketiga kelompok alga tersebut merupakan alga ekonomis penting. Menurut sejarah, pada mulanya orang menggunakan alga hanyalah sebagai sayuran karena tidak berbahaya saat dimakan, tetapi saat ini telah dikembangkan melalui penelitianpenelitian, ternyata alga dapat dimanfaatkan dalam berbagai bidang industri(Bold \& Wynne, 1985). Selain itu 
beberapa peneliti mengemukakan bahwa alga juga merupakan salah satu sumber senyawa bioaktif yang sangat bermanfaat yaitu pigmen (Trono, 1997). Saat ini, pigmen yang berasal dari organisme laut telah menjadi perhatian sejumlah peneliti, selain warna yang dihasilkan juga banyak manfaat bagi manusia terutama dari segi kesehatan. Oleh karena pentingnya peranan pigmen, sehingga menjadi pendorong untuk melakukan penelitian terhadap jenis pigmen klorofil pada alga jenis $P$. australis Hauck yang diambil dari beberapa tempat di Perairan laut Sulawesi.

\section{METODE PENELITIAN}

Pengambilan sampel alga $P$. australis Hauck dilakukan di Perairan Laut Sulawesi. Selanjutnya sampel dibawa ke Laboratorium Toksikologi dan Farmasitika Laut FPIK UNSRAT untuk diidentifikasi kembali (Trono, 1997). Kemudian dilakukanproses ekstraksi dengan pelarut organik. Analisis pigmen dengan menggunakan Spektrofotometer pada panjang gelombang $380-700 \mathrm{~nm}$ dilakukan di Balai POM Manado.
Perhitungan kandungan klorofil pada alga dalam aseton digunakan rumus (Jeffrey \& Humphrey, 1975) sebagai berikut :

Klorofil $-\mathrm{a}=11.85 \mathrm{~A}_{664}-1.54 \mathrm{~A}_{647}-0,08 \mathrm{~A}_{630}$ Dimana A adalah absorban pada panjang gelombang (nm). Untuk mendapatkan nilai klorofil dalam satuan $\mathrm{mg} / \mathrm{l}$ maka rumus di atas harus dikalikan lagi dengan faktor "k" yang ditentukan oleh volume ekstrak (ml) dibagi hasil kali volume saring (I) dengan panjang kuvet (cm).

\section{HASIL DAN PEMBAHASAN}

Hasil serapan pigmen ekstrak total dengan spektrofotometer pada gambar 1 di bawah initerlihat adanya beberapa puncak menunjukkan bahwa terdapat beberapa jenis pigmen. Pigmen klorofil mempunyai 2 puncak maksimum yang berbeda pada panjang gelombang 432,20 nm dan $664 \mathrm{~nm}$.

Kurva pigmen klorofil dari Perairan Tongkaina puncak gelombang sekitar $433 \mathrm{~nm}$ dan 664,20 nm. Untuk pigmen klorofil yang diambil dari perairan Blongko mempunyai panjang gelombang maksimum 431,4 dan $662,60 \mathrm{~nm}$.

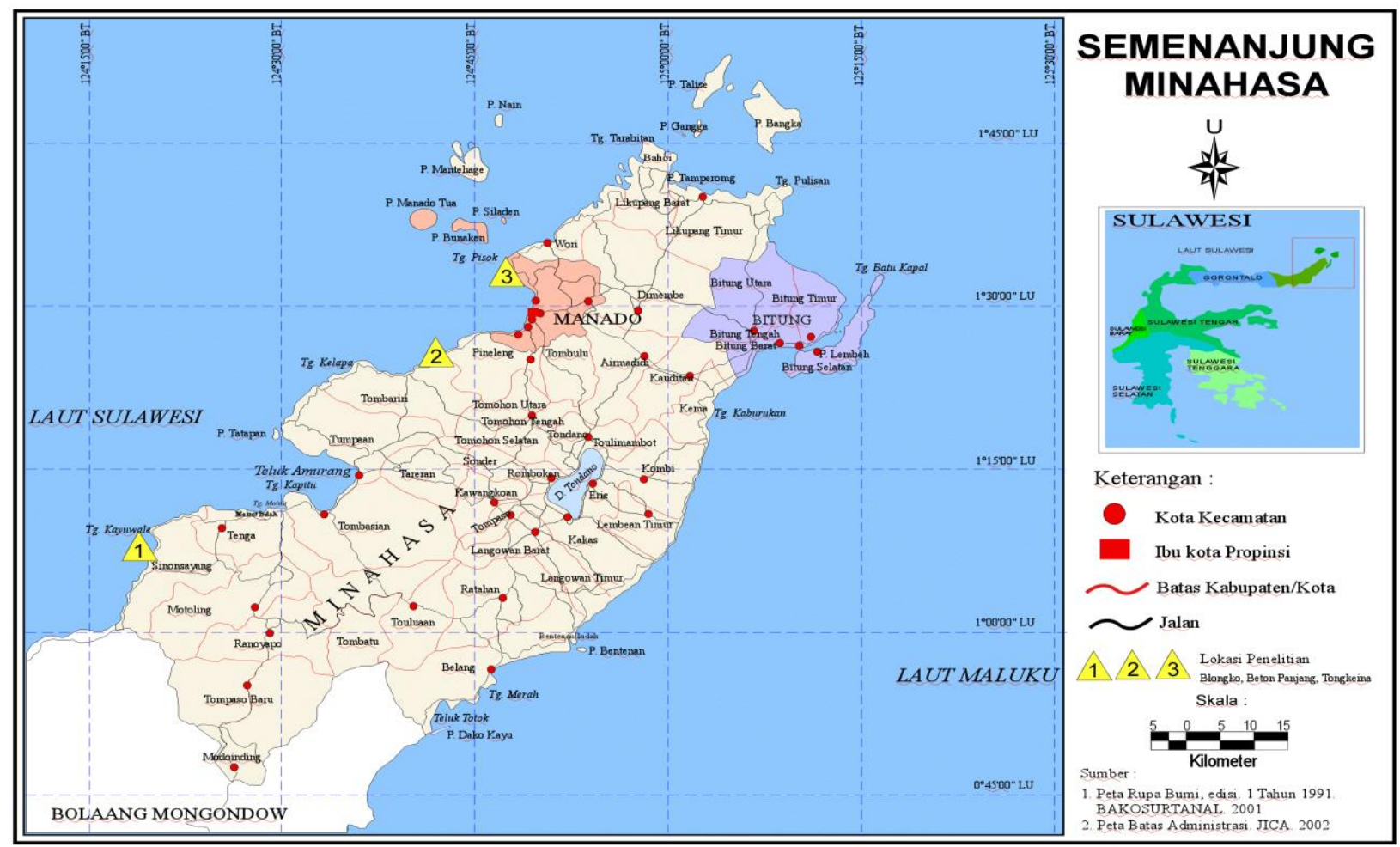

Gambar 1. Lokasi Penelitian 


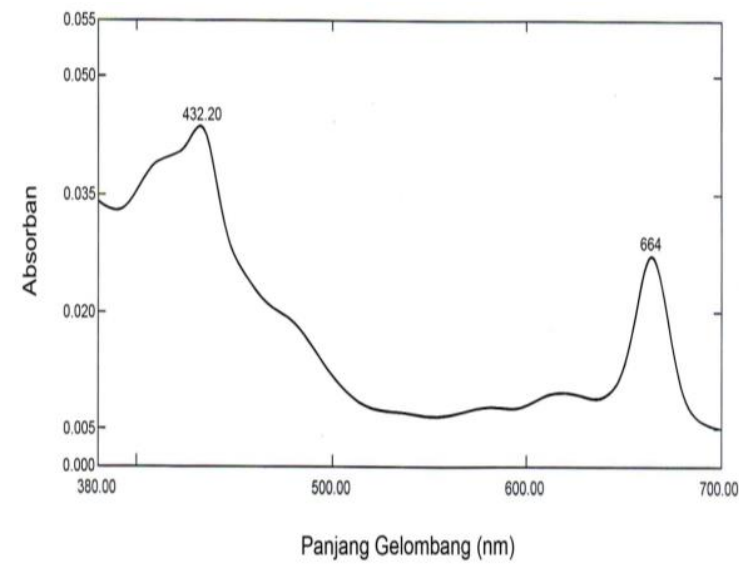

Gambar 2. Spektrogram pigmen klorofil total alga $P$. australis Hauck yang diambil dari Perairan Tanjung Kalasey

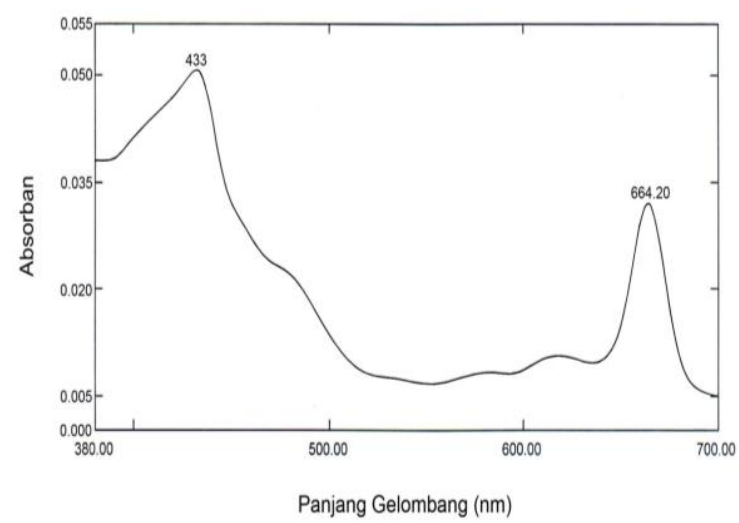

Gambar 3. Spektrogram pigmen klorofil total alga $P$. australis Hauck yang diambil dari Perairan Tongkaina.

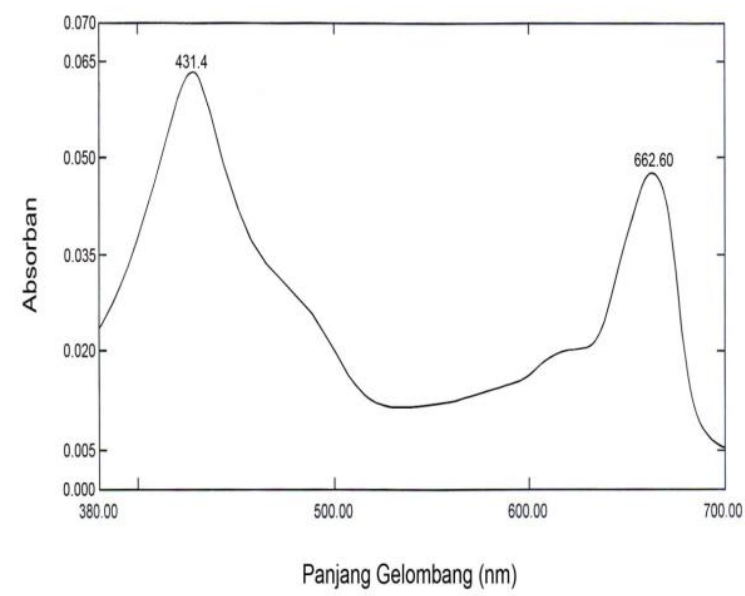

Gambar 4. Spektrogram pigmen klorofil total palga $P$. australis Hauck yang diambil dari Perairan Blongko Kecamatan Sinonsayang.
Hasil perhitungan konsentrasi klorofil-a pada ketiga lokasi penelitan dengan kurva serapan pada panjang gelombang 380-700 nm dengan pengembang PE : Aseton (80:20), menunjukkan konsentrasi tertinggi di Perairan Blongko yaitu $0,381 \mu \mathrm{g} / \mathrm{ml} \mathrm{di}$ PTK3 dengan kisaran 0,298 - 0,381 $\mu \mathrm{g} / \mathrm{ml}$ dan terendah di Perairan Tongkaina yaitu $0,143 \mu \mathrm{g} / \mathrm{ml}$ di PT3 dengan kisaran $0,143-0,30 \mu \mathrm{g} / \mathrm{ml}$.

Hasil perhitungan rata-rata konsentrasi klorofil a dapat dilihat pada Tabel 1.

Ekstrak pigmen alga coklat $P$. australis Hauck dalam petroleum eter (PE) berwarna hijau, disebabkan oleh pigmen klorofil, selanjutnya dipekatkan dengan menggunakan evaporator, kemudian ditentukan serapan spektrofotometer.

Pemisahan senyawa pigmen dari alga coklat $P$. australis Hauckmenggunakan pengembang petroleum eter (PE) dan aseton yang bersifat semipolar dengan perbandingan $80: 20$.

Hasil ekstrak pigmen total dilakukan pemisahan dengan

Tabel 1. Hasil Perhitungan Kurva Serapan Pada Panjang Gelombang 380-700 nm dengan pengembang PE : Aseton $(80: 20)$

\begin{tabular}{|c|c|}
\hline $\begin{array}{c}\text { Lokasi } \\
\text { Penelitian }\end{array}$ & $\begin{array}{c}\text { Rata- } \\
\text { rataKonsentrasi } \\
\text { Klorofil a } \\
(\mu \mathbf{g} / \mathbf{m l})\end{array}$ \\
\hline \multicolumn{2}{|c|}{ Perairan Tanjung Kalasey } \\
PTK 1 & 0,327 \\
PTK 2 & 0,339 \\
PTK 3 & 0,294 \\
\hline \multicolumn{2}{|c|}{ Perairan Tongkaina } \\
PT 1 & 0,303 \\
PT 2 & 0,30 \\
PT 3 & 0,143 \\
\hline \multicolumn{2}{|c|}{ Perairan Blongko } \\
PB 1 & 0,298 \\
PB 2 & 0,381 \\
PB 3 & 0,325 \\
\hline
\end{tabular}




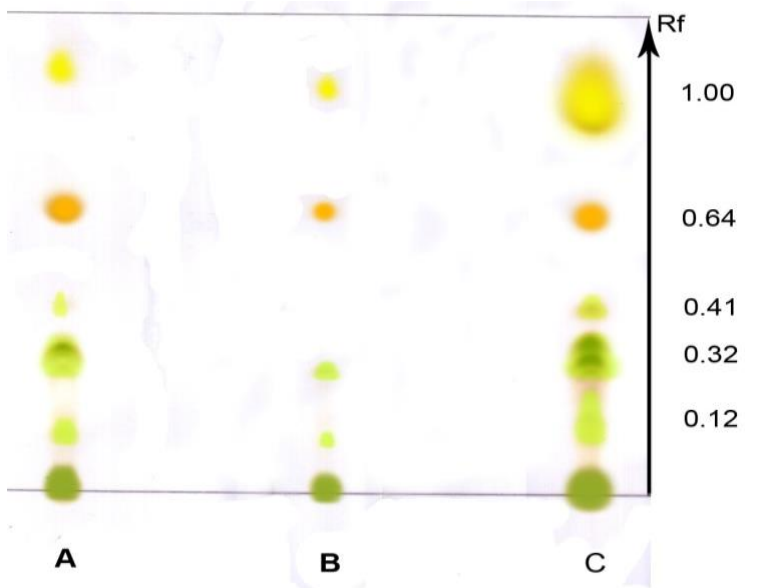

Ket : A. Perairan Teluk Kalasey

B. Perairan Tongkaina

C. Perairan Blongko

Gambar 5. Kromatogram hasil uji KLT Pigmen Klorofil Total dengan Pengembang PEdan Aseton (80 : 20) di ketiga Lokasi Penelitian

Kromatografi Lapis Tipis (KLT). Pemisahan ini berfungsi untuk menentukan jenis pigmen pada ekstrak $P$. australis Hauck. Pemisahan ini dilakukan di atas pelat silika gel tipe 60 ukuran $10 \mathrm{~cm} \times 10 \mathrm{~cm}$ dengan menggunakan larutan pengembang petroleum eter (PE) dan aseton (80 : 20). Setelah dilakukan uji kromatografi lapis tipis untuk menghasilkan pigmen maka pigmen diekstrak kembali untuk menghitung Rf nya. Setiap fraksi yang diperoleh dari pemisahan dengan KLT.

Hasil migrasi pigmen total pada pelat silika gel. Setiap fraksi diekstrak kembali dalam petroleum eter kemudian dilihat bentuk kurvanya melalui spektrofotometer.

Bentuk spektogram pada fraksi satu membentuk tiga puncak utama. Puncak ketiga serapannya lebih rendah jika dibandingkan dengan klorofil-a. Serapan maksimum puncak pertama terdapat pada panjang gelombang 420 $\mathrm{nm}$, sedangkan puncak serapan maksimum puncak kedua terdapat pada panjang gelombang $665 \mathrm{~nm}$ yang menampilkan bentuk dari kurva serapan untuk jenis pigmen klorofil-b (Goodwin, 1988).

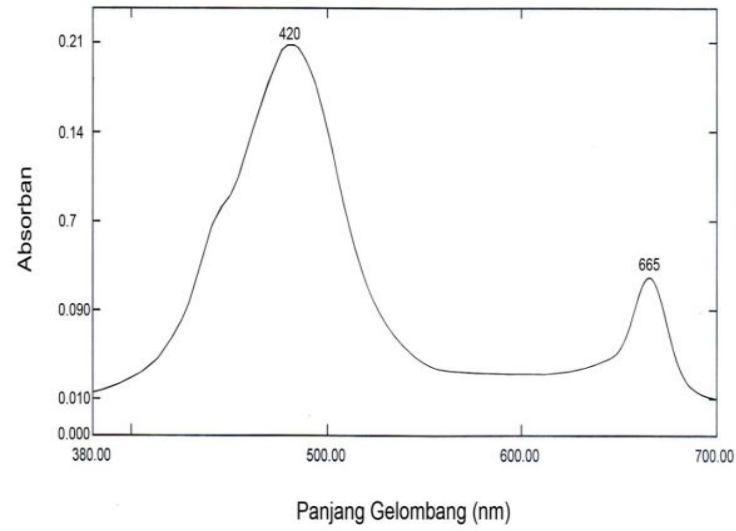

Gambar 6. Spektrogram pigmen klorofil b (Jupin dan Lamant, 1997) dengan pengembang petroleum eter dan aseton (80:20).

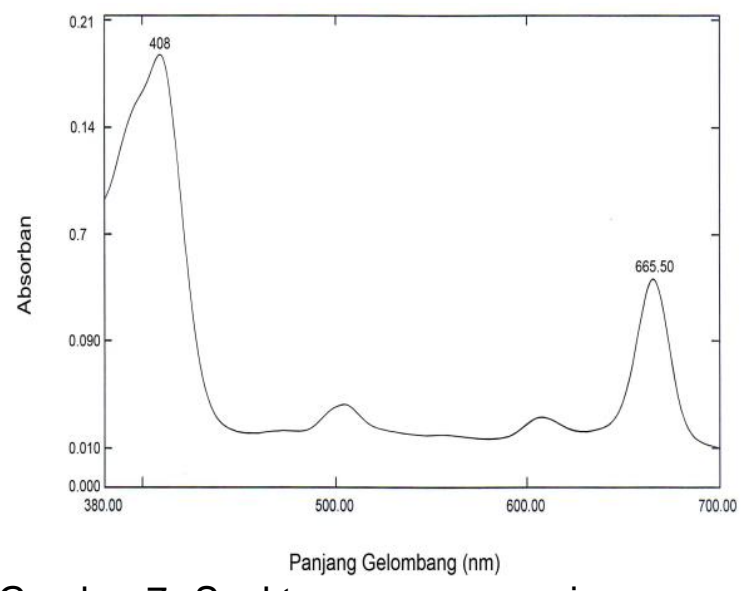

$$
\begin{gathered}
\text { Gambar 7. Spektrogram pigmen } \\
\text { klorofil-a (Jupin dan } \\
\text { Lamant, 1997) dengan } \\
\text { pengembang petroleum } \\
\text { eter dan aseton }(80: 20) .
\end{gathered}
$$

Pada fraksi ke-2 di atas pelat silika gel berwarna hijau, dari ekstrak pigmen total membentuk kurva dengan serapan maksimum spektrofotometer pada panjang gelombang 408 - 665.50 $\mathrm{nm}$, teridentifikasi sebagai pigmen klorofil-a. Pigmen klorofil-a menunjukkan adanya dua puncak pada kisaran panjang gelombang $400-700$ $\mathrm{nm}$. Bentuk kurva pigmen klorofil-a pada fraksi ke-4 dapat dilihat pada Gambar 6.

Demikian juga fraksi ke-3, membentuk kurva dengan serapan maksimum spektrofotometer pada panjang gelombang $410-660 \mathrm{~nm}$. 


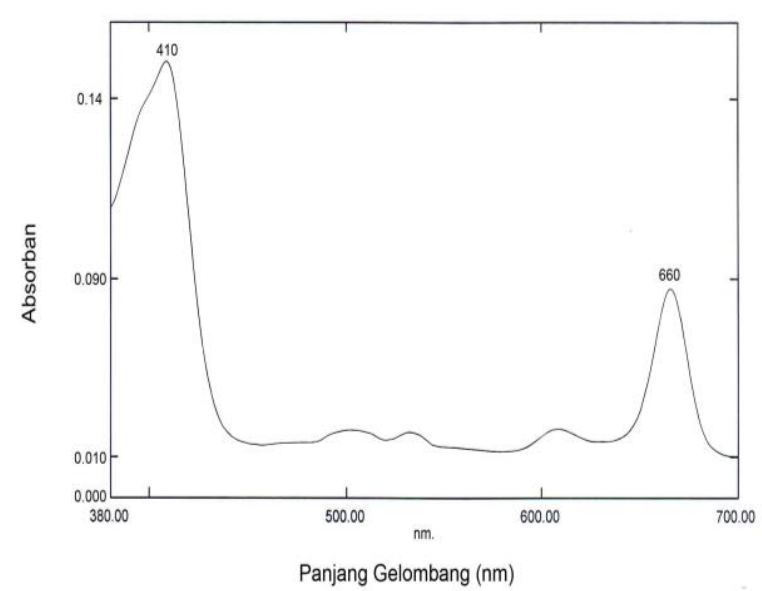

Gambar 8. Spektrogram pigmen klorofil-a (Jupin dan Lamant, 1997) dengan pengembang petroleum eter dan aseton (80:20).

Teridentifikasi juga sebagai pigmen klorofil-a (Gambar 7). Pigmen klorofil-a juga ditemukan pada penelitian Masloman (2003) pada alga Turbinaria ornata. Demikian juga pigmen klorofil-a ditemukan pada alga mikro Chaetoceros sp.dalam penelitian Tulalo (1999).

Pigmen klorofil-a merupakan pigmen utama dalam proses fotosintesis (Dawes, 1981). Selanjutnya (Harborne, 1987) mengemukakan bahwa klorofil-a adalah katalisator fotosintesis yang penting dan terdapat pigmen hijau dalam jaringan tumbuhan. Terdapat pada kloroplas dalam jumlah yang relative banyak sering terikat longgar dengan protein, tetapi mudah di ekstraksi dalam pelarut lipida seperti PE dan Aseton. Dari hasil KLT dan serapan maksimum spektrofotometer alga coklat $\quad P$. australis Hauck mengandung pigmen klorofil-a yang dominan.

\section{KESIMPULAN}

Jenis pigmen yang ditemukan pada ekstraksi pigmen $P$. australis Hauck adalah klorofil-a, klorofil-b. Konsentrasi rata-rata klorofil-anilai tertinggi di Perairan Blongko yaitu $0,381 \mu \mathrm{g} / \mathrm{ml}$ di PTK3 dengan kisaran $0,298-0,381 \mu \mathrm{g} / \mathrm{ml}$ dan terendah di
Perairan Tongkaina yaitu $0,143 \mu \mathrm{g} / \mathrm{ml}$ di PT3 dengan kisaran 0,143 - 0,30 $\mu \mathrm{g} / \mathrm{ml}$.

\section{DAFTAR PUSTAKA}

Bold, H., Wynne, M. 1985. Introduction to The Algae; Algae News Book Ltd. London: International Scholary research.

Dawes, C.J. 1981. Marine Botany: Jonh Wiley and Sons.Inc. Canada.

Goodwin, T. W. 1988. Plant Pigmentas; San Diego : Academic Press Inc.

Harborne, J.B. 1987. Metode Fitokimia Penuntun Cara Modern Menganalisis Tumbuhan. Bandung : Penerbit ITB Bandung.

Jeffrey, S.W. and Humphrey, G.F. 1975. New Spectrophotometric Equations For Determining Chlorophylls a, b, $c_{1}$ and $c_{2}$ Inb Higher Plants, Algae and Natural Phytoplankton. Biochem Physiol, 167 (88), pp. 191 - 194.

Jupin, H. and Lamant, A. 1997. La Photosynthese. Paris : Masson.

Masloman, I. (2003) Analisis Kandungan Pigmen Pada Bagian Daun (Blade), Batang (Stipe) dan Reseptakel dari Alga Coklat Turbinaria ornate. Unpublished Skripsi, FPIK UNSRAT.

Matsjeh, S. 1999. Thin Layer Cromatography. International Journal of Chemical, 6 (1), pp. 7296.

Trono, G.C. 1997. Field Guide and Atlas of the Seaweed; National Book Store. Philippines: Publisher Metro Manila.

Tulalo, Y. 1999. Analisis Pigmen Pada Beberapa Jenis Alga Mikro. Unpublished Skripsi, FPIK UNSRAT.

Vandenhoek, C.D., Maunand Jahns, H.M. 1995. Algae an Introduction to Phycology; Algae book. New York: Cambridge University. 